\title{
Drought Analyses of the Horné Požitavie Region (Slovakia) in the Period 1966-2013
}

\author{
Jaroslav Vido (iD, ${ }^{1}$ Paulína Nalevanková, ${ }^{1}$ Ján Valach, ${ }^{2}$ Zbyšek Šustek, ${ }^{3}$ \\ and Tsegaye Tadesse ${ }^{4}$ \\ ${ }^{1}$ Department of Natural Environment, Faculty of Forestry, Technical University in Zvolen, T.G. Masaryka 24, \\ 96001 Zvolen, Slovakia \\ ${ }^{2}$ Department of Land and Water Resources Management, Faculty of Civil Engineering, Slovak University of Technology, \\ Radlinského 11, 81005 Bratislava, Slovakia \\ ${ }^{3}$ Institute of Zoology SAS, Dúbravská cesta 9, 84506 Bratislava, Slovakia \\ ${ }^{4}$ National Drought Mitigation Center, University of Nebraska, 819 Hardin Hall, 3310 Holdrege Street, P. O. Box 830988, Lincoln, \\ NE 68583-0988, USA \\ Correspondence should be addressed to Jaroslav Vido; vido@tuzvo.sk
}

Received 30 January 2019; Accepted 30 May 2019; Published 11 July 2019

Academic Editor: Herminia García Mozo

Copyright $\odot 2019$ Jaroslav Vido et al. This is an open access article distributed under the Creative Commons Attribution License, which permits unrestricted use, distribution, and reproduction in any medium, provided the original work is properly cited.

This study focuses on the characterization of historical drought occurrences in the Horné Požitavie region of Slovakia over the period 1966-2013 using Standardized Precipitation-Evapotranspiration Index (SPEI). Trend analyses were evaluated by the Mann-Kendall (MK) test as well as cumulative sum of rank difference (CRD) test. The results showed that drought occurs in the region regularly (recurrent climate feature), while the trend analysis indicated the trend toward more arid climatic conditions. However, CRD trend analyses showed that the subtrend changed direction toward less drier conditions in the late 1980s and early 1990s. Analyses of SPEI trends in individual months showed a decreasing trend of drought occurrences during the cold months of the year (i.e., October to March), while an increasing trend was indicated from April to August. The evaluation of the impact of drought on agricultural production based on the oilseed rape yield indicated that drought represents a significant natural risk for the agrarian sector of the region. In addition, August value of the SPEI for six months was evaluated as a good indicator of drought impacts on agriculture. The trend analyses revealed no significant increase of drought impacts on agricultural production within the studied period.

\section{Introduction}

Drought is a natural disaster that affects several aspects of the human society. Because drought is a creeping phenomenon (gradual unnoticeable onset), its impacts could be devastating [1]. This gradual onset of drought results from the cumulative precipitation deficit that could be worsened by evapotranspiration total, which represents a passive component of climatic water balance [2].

Because of this, drought episodes have wide-range impacts [3, 4]. Extreme forest fires in Mediterranean [5], hydrological drought throughout Europe [6], or frequent agricultural drought in Central Europe $[7,8]$ are demonstration of some drought impacts. In case of prolonged drought episodes, socioeconomic and pure economic losses become visible [9-11].

Because of this, identifying the historical patterns, trends, and impacts of droughts provides valuable information for disaster prevention and proactive activities that are aimed at mitigating droughts and reducing vulnerability of the society in the future [12].

Prolonged and devastating drought episodes in last few decades have been thoroughly studied [9, 11, 13-15].

These studies are mostly carried out using a variety of drought indices and indicators based on specific application and location [4, 16-18]. Among the variety of indices, Standardized Precipitation Index (SPI) [19], Standardized Precipitation-Evapotranspiration Index (SPEI) [20], and 
Palmer Drought Severity Index (PDSI) [21] are frequently used.

However, much of the research activities have focused on drought monitoring and its indication and less on the drought impact assessment on the affected sectors [22] except agriculture [8, 23-27].

Hydrological drought was discussed by Zeleňáková et al. [28], precipitation and temperature trends were discussed by Melo et al. [29] and Zeleňáková et al. [30], and meteorological drought was assessed by Labudová et al. [31]. Palmer Drought Severity Index has been applied by Zuzulová and Šiška [32] in order to identify drought in Western Slovakia. Meteorological drought occurrence in Tatra National Park was analyzed by Vido et al. [33], and drought in altitudinal vegetation zones of Slovakia was analyzed by Škvarenina et al. [34].

Although this drought impact assessment has been also carried out, ecological aspects of drought occurrence have been analyzed by Šustek and Vido [35, 36], drought impacts on forest ecosystems were analyzed by Nalevanková et al. [37] and Škvareninová et al. [38], and application of the SPI in forest drought assessment was carried out by Vido et al. [39].

However, agricultural drought assessment in Slovakia has previously been analyzed rarely. Spatial aspects of agricultural drought have been assessed by Takáč et al. [40], and comparison of the SPI and SPEI applicability for agricultural drought impact assessment in selected lowland areas has been done by Labudová et al. [25]. This is interesting because these analyses were widely assessed in the adjacent countries $[8,24,26,27]$.

The region of interest is located at the northeastern border of the geomorphological unit Danubian Lowland. The region is well known as agricultural and wine lands (Nitra wine region). In addition, a significant part of the population is employed in agriculture. In the region, also Arborétum Mlyňany is situated as a unique workplace of the Slovak Academy of Sciences (SAS) and part of the network of International Phenological Gardens (IPG). Because of these natural, social, and economical features, the region represents an area that is potentially strongly threatened by drought.

Despite this, the region of Horné Požitavie was out of drought assessment interest. Therefore, we decided to analyze drought within the period 1966-2013 based on data from the meteorological station located in Arborétum Mlynnany (SAS) (latitude $48.322^{\circ} \mathrm{N}$, longitude $18.369^{\circ} \mathrm{E}$, and altitude $180 \mathrm{~m}$ a.s.l.).

The objectives of this study are (i) to generate the historical SPEI values for the period 1966-2013 to identify the drought occurrences, (ii) to identify the drought trends during the examined period at a monthly time step, and (iii) to examine the drought impact on agricultural production of the region using the oilseed rape as a case study.

\section{Materials and Methods}

2.1. Study Area. The Horné Požitavie region is located at the northeastern border of the geomorphological unit
Danubian Lowland. The region has wavy relief compared to central Danubian Lowland with a flat geomorphology. The area has varied geological substrates (clay, gravel, and sands), which are covered by Quaternary sediments (loess) and very fertile soils (black and brown earths). Horné Požitavie is a relatively homogeneous region from the climatological point of view because of the small area $\left(600 \mathrm{~km}^{2}\right)$ and low altitudinal amplitude (from 140 to $280 \mathrm{~m}$ above the sea level) [41].

The annual average air temperature of the area is $9.73^{\circ} \mathrm{C}$. The average air temperature is $20.2^{\circ} \mathrm{C}$ in July (warmest month) and $-1.2^{\circ} \mathrm{C}$ in January (coldest month). The absolute maximum of air temperature $\left(38.3^{\circ} \mathrm{C}\right)$ was recorded on August 8, 2013, and the same maximum was earlier observed on July 20, 2007. The historical record of minimum temperature $\left(-27.2^{\circ} \mathrm{C}\right)$ was observed on January 13,1987 . The annual average precipitation total is $584 \mathrm{~mm}$. The average precipitation total from April to September is $336 \mathrm{~mm}$. The absolute maximum of daily precipitation total $(65.2 \mathrm{~mm})$ was recorded on June 1, 2010 [29].

Because of the specific climate and fertile soils, landscape of the region is used mainly for agriculture, wine production, and agrotourism. In addition, Arborétum Mlyňany belonging to the International Phenological Gardens (IPG) network contributes to the landscape diversity of the region. The arboretum was founded in 1892 as one of the first largescale (40 ha) collections of evergreen trees in Central Europe [41].

2.2. Data. Meteorological data were obtained from the meteorological station situated in Arborétum Mlyňany (Figure 1). The meteorological station was established as a representative climatological station for the region [41, 42]. For study purposes, monthly precipitation totals and monthly mean air temperatures were obtained from the meteorological station (operated by the Slovak Hydrometeorological Institute) in Arborétum Mlyňany for the period from 1966 to 2013.

Preliminary data processes (i.e., quality check, homogenization, and preparation for the end user) were carried out by the Slovak Hydrometeorological Institute according to internal and international standards of the World Meteorological Organization [43]. Crop yield data applied in this study were obtained from the Statistical Office of the Slovak Republic.

2.3. Standardized Precipitation-Evapotranspiration Index (SPEI). The SPEI is a relatively new drought index [20]. The principle of its calculation is based on Standardized Precipitation Index (SPI) [19], which evaluates the deviations of precipitation from the long-term normal at different time scales (usually from 1 to 24 months). The SPI has long been used for drought monitoring in several countries in the world [44]. One of the limitations of the SPI is that it does not include the passive components of the hydrological regime (i.e., evapotranspiration). Vicente-Serrano et al. [20] used both precipitation and potential evapotranspiration (PET) to generate the SPEI values that include the deviation 


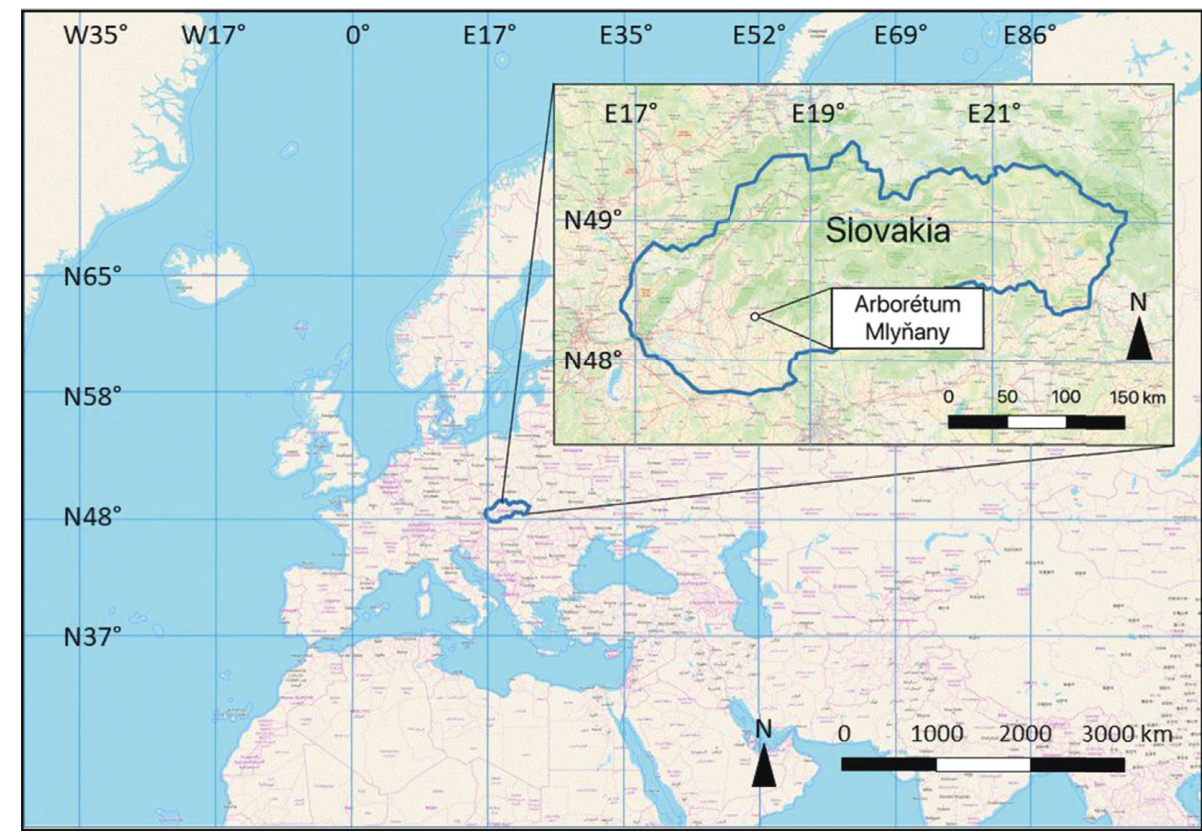

Figure 1: Localization of the meteorological station in Arborétum Mlyňany in the Horné Požitavie region.

of the whole climatic balance (P-PET) from the normal (i.e., positive values represent positive balance, and vice versa). Following the methodology of Vicente-Serrano et al. [20], a drought episode starts (similar to the SPI methodology) when a negative value of the index appears and lasts until the first positive value. However, it is required that the value during the specific episode must reach or exceed -1 at least one month. The calculation of the potential evapotranspiration using the SPEI is based on the equation of Thornthwait [45]. Calculation of the SPEI requires a time series of at least thirty years of monthly average air temperatures and monthly precipitation totals from each station. In this study, we calculated the index for the Horné Požitavie region using the climatic values from the station in Arborétum Mlyňany from 1966 to 2013.

In this study, we evaluated drought using 1-, 6-, and 12month SPEIs. The 1-month SPEI was used to analyze the trends of aridity and humidity during individual months. The 1-month SPEI was also used to identify a month or a combination of months that were critical for the oilseed rape production. A more detailed description of this procedure is given below.

The 12-month SPEI was used to evaluate the occurrence and the trends of long-term droughts. The application of the 12-month SPEI is based on the hypothesis that it could show a relatively long-term (a year) cumulative drought impact (negative climatic balance). In addition, according to Heim [46], social and economic drought could be revealed over 12 months.

The character of such a long-term drought negatively affects the whole set of human activities and needs, starting from the lack or high prices of agricultural and food products [47], through the reduction of operational efficiency of agricultural enterprises, leading to the dismissal of employees [48], up to the critical impacts on water management, such as a significant drop in the water level of large water reservoirs [49], which leads to a forced reduction in the flow of watercourses with consequences in the dependent industry, or directly in the supply of drinking water to the population [50]. However, it must be noted that the time scale of 12 months was determined arbitrarily, after a critical evaluation of available scientific papers and empirical information about various drought impacts in different sectors of the economy and the environment in the Slovak Republic. Following the published methodology [20], we chose -1.5 as a threshold value of the SPEI that represented extreme drought (2.3\% of all cases).

For this study, we used log-logistic distribution function in SPEI computation as originally proposed by VicenteSerrano et al. [20].

Since the meteorological station in Arborétum Mlyňany cooperates with the phenological station in Arborétum Mlyňany as a part of the network of International Phenological Gardens (IPG), we considered to keep the SPEI computation method in the original form to be comparable with other potential studies in the future. However, after considering the findings of Stagge et al. $[51,52]$ and VicenteSerrano and Beguería [53], we used the Shapiro-Wilk test [54] to evaluate the normality of the computed SPEI. All the computed SPEIs were normally distributed (not shown), and therefore, the log-logistic distribution function was applied.

2.4. Trend Analyses. Two nonparametric methods for trend analyses were applied:

(i) Mann-Kendall (MK) trend test

(ii) Cumulative sum of rank difference (CRD) test

The Mann-Kendall test $[55,56]$ is a standard nonparametric test for trend detection [57-59]. However, as 
written by Onyutha [58], the Mann-Kendall test is a pure statistical method, so there are not enough insights about specifics of the studied trends. Thus, in cases where trend results are to be applicable for decision on operational practices, it is necessary to know more about trend behaviour on a temporal scale. Therefore, we decided to use also the CRD test. This method combines both statistical and graphical approaches in trend analyses, and therefore, it is possible to interpret computed trend analyses in a detailed manner. A detailed description of the method and computation procedures is in the study by Onyutha $[58,60,61]$.

A combination of the CRD test with the MK test is able to bring deep insights into trend behaviour (i.e., cyclical anomalies and abrupt changes in trend).

In our case, we used rescaled series and CRD plots of the SPEIs. Computation of the CRD was carried out using the CRD-NAIM v3 tool, which was downloaded together with its user manual from the link https://sites.google.com/site/ conyutha/tools-to-download (accessed on July 31, 2018).

The computations based on monthly scale CRD parameters were put in the tool as follows:

(i) Significance level set at $5 \%$

(ii) Time scale representing moving average 60 (60 months $=5$ years)

(iii) Initial block set at 10

(iv) Number of Monte Carlo runs for resampling set at 1000 (default setting)

The MK test was used as a general indicator of trend toward aridity or humidity, and CRD graphical outputs were used as an additional indicator of changes in trend directions throughout the studied period. For the MK test, the significance level was by default set at $\alpha=0.05$. However, in order to gain sensitive information on trend significance (in trend detection of individual months), trends were tested from $\alpha=0.05$ to $\alpha=0.25$.

2.5. Impacts of Drought on Agricultural Production. The evaluation of the drought impact on agricultural production in the Horné Požitavie region was performed by applying a modified method [9] based on searching for the highest and logical correlation (from the agricultural point of view) between the values of the SPEI representing individual months or a combination of months and crop yield ( $t / h a)$ in the particular year. This method was already applied by several authors [8, 23-27]. We found the highest correlation of the 1-month SPEI and oilseed rape yield ( $t / h a)$ in the period starting from March to August between the years 1985 and 2012. Correlation between the SPEI and the oilseed rape yield ( $\mathrm{t} / \mathrm{ha}$ ) $R^{2}$ was 0.4005 . Based on these results, we used an August value of the SPEI for six months to express the impact of drought on agricultural production. The reason for using a shorter period for the correlation analysis in comparison to SPEI data series (1966-2013) was the limited availability of statistical data on oilseed rape yield in the region. Figure 2 presents the correlation of oilseed rape yield ( $\mathrm{t} / \mathrm{ha}$ ) and August values of the SPEI for six months. The correlation is significantly biased by the year 2010, in which the precipitation was excessive. Because of this, the year 2010 was considered an outlier and omitted in the correlation analyses.

The correlation of the SPEI was significant at the $\alpha=0.05$ significance level. In this case, statistical significance was evaluated by a significance test of correlation coefficient.

\section{Results and Discussion}

3.1. Trend Analyses of SPEI in the Period 1966-2013. The evaluation of the drought occurrence using a 12-month SPEI showed a cyclical alternation of dry episodes with episodes of a positive climate balance. According to the index, extremely dry periods were August 1967-January 1968, August 1982-June 1984, August 1989-March 1994, May 1997-May 1999, June 2000-August 2001, May 2003-May 2004, December 2006-June 2008, and September 2011-April 2013. As patent from Figure 3, less extreme dry periods occurred also between the listed periods.

It is to be noted that a long-term episode of drought could have undetectable and unclear impacts in real conditions that lead to damages immediately after the drought occurrence. The weather course and timing of the drought episode are therefore important. For example, an episode of drought in December has relatively latent impacts on agricultural production or some ecological relationships but can rapidly reduce water levels in water reservoirs and the groundwater level. This event is called "green drought" [62]. However, it is probable that, in spite of no immediately evident drought consequences in the dormancy period, the drought cumulation can result in real and quantifiable impacts in next months, if the weather course is unfavourable. Such a situation occurred in 2011 and 2012 in eastern and northern Slovakia, when an extreme reduction of water reserves in big water dams of Liptovská Mara, Ružín, and Domaša was recorded [49].

The trend analysis of the time series of the 12-month SPEI revealed the continuing decline in the number of relatively humid episodes and the increase in the number of dry episodes over the examined period. The MK trend test proved the significance of the trend at the $\alpha=0.05$ significance level. Nevertheless, the question of causes of this arid trend needs to be clarified because the results of Bell et al. [62] showed that the precipitation fluctuations at this station had a balanced trend over the same period (1966-2013). The answer follows from the comparison of the long-term trend of average annual air temperature and the trend of annual precipitation totals at the station (Figure 4).

Figure 4 shows that the difference between conclusions of this study and of Vido et al. [63] (based on Standardized Precipitation Index only) results from the usage of different indexes and different interpretations. This indicates that the SPEI is much more suitable for drought analysis from the viewpoint of a significant increase in air temperature during the last decades leading to a higher evapotranspiration. The 


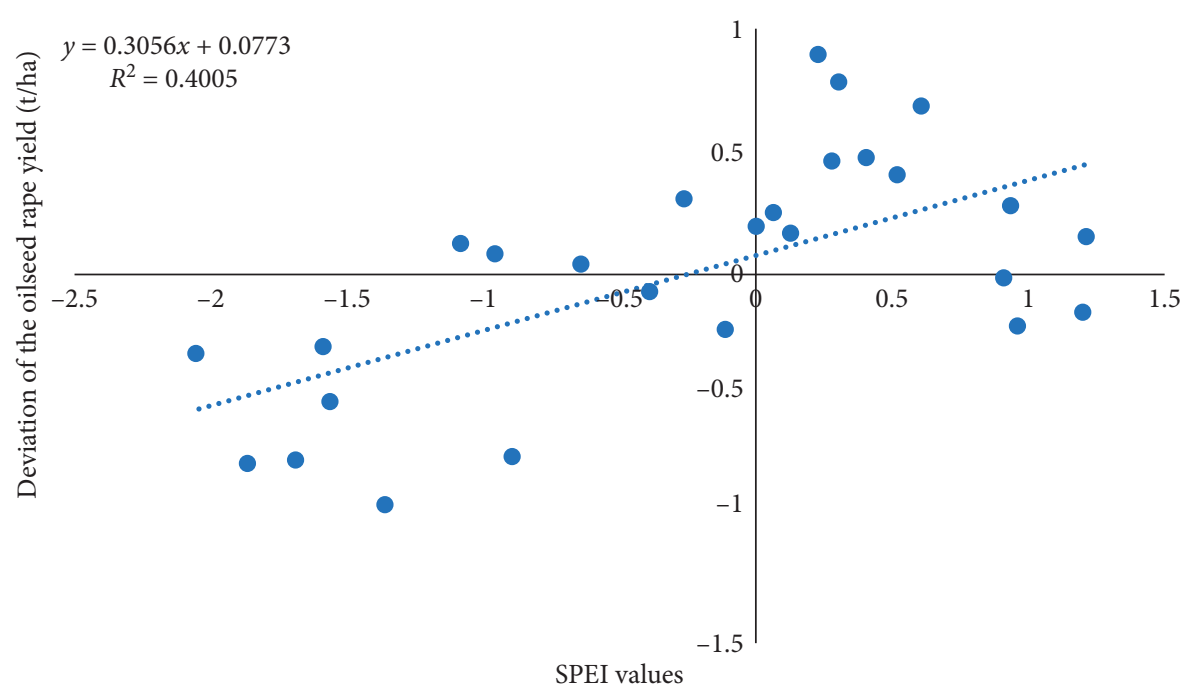

FIgure 2: Correlation between August values of the SPEI for 6 months and yield of oilseed rape (t/ha).

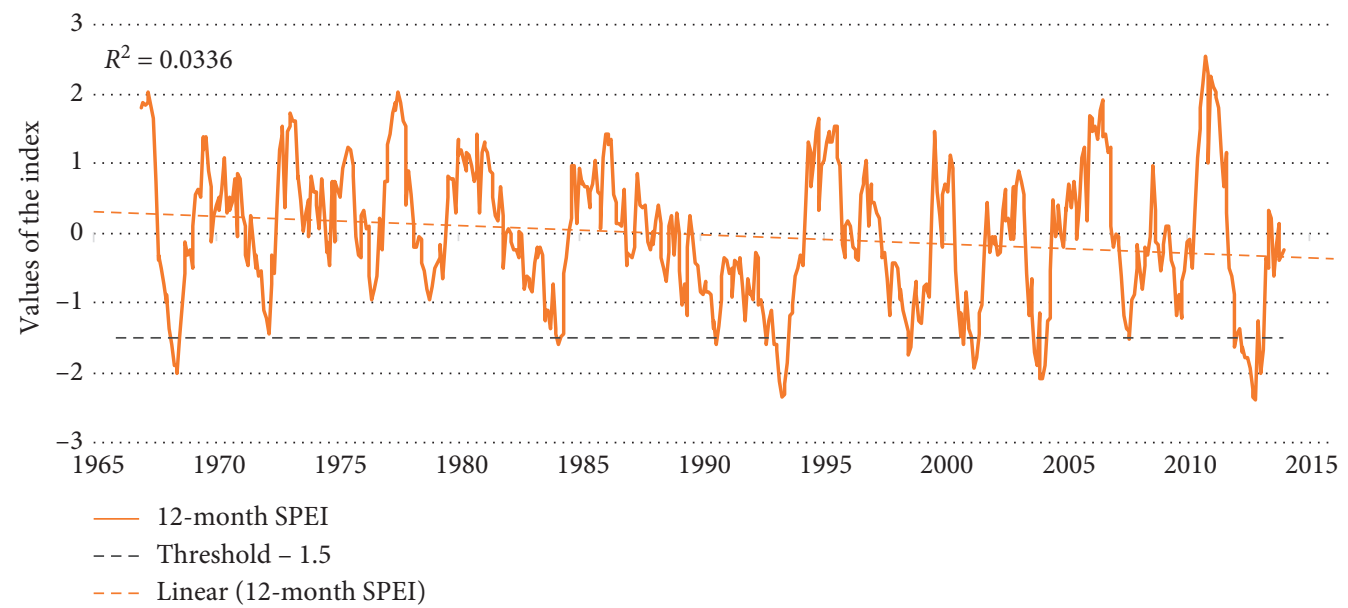

Figure 3: Temporal course of a 12-month SPEI with the linear trend of the time series and an indication of the threshold value of the index $(-1.5)$.

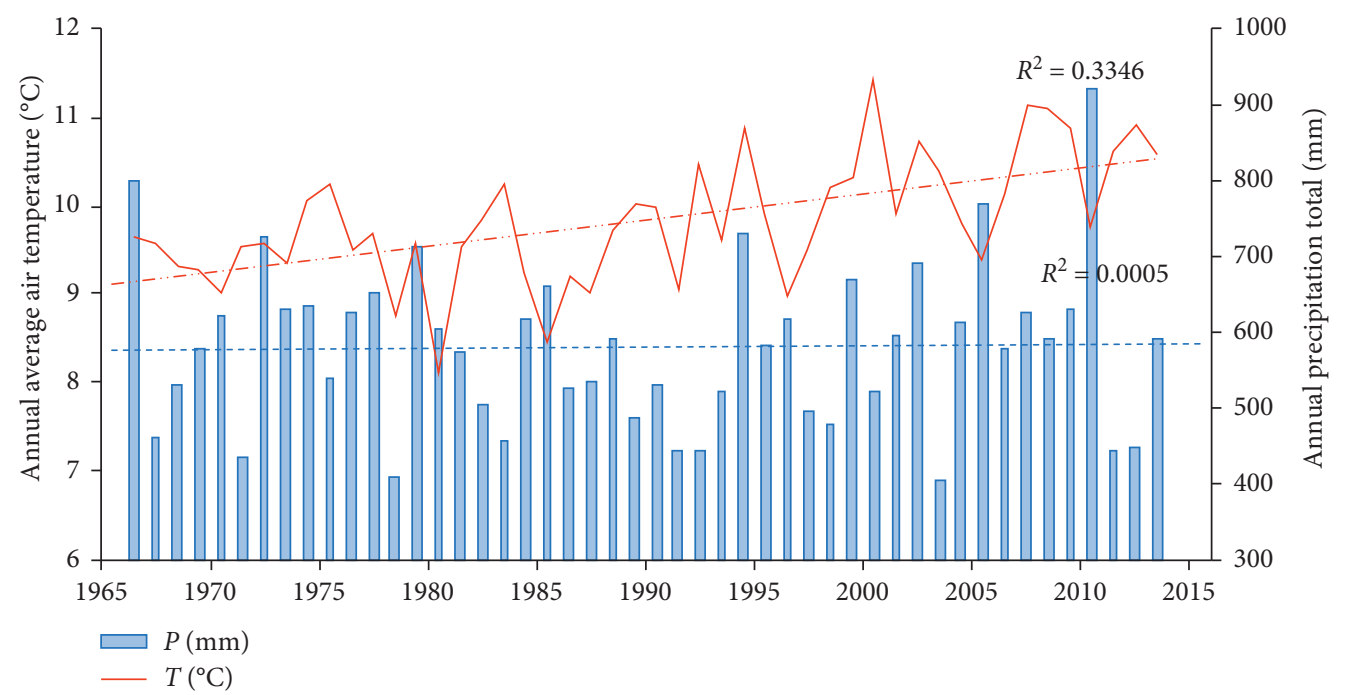

Figure 4: Trend analysis of average annual air temperature and annual precipitation totals at the station in Arborétum Mlyňany in 1966-2013. 
results of the trend analysis suggest unfavourable prospects for the region in connection with the occurrence of drought episodes. From this perspective, future development and use of regional natural resources sensitive to drought becomes questionable. Of course, this state could be moderated by additional financial investment to irrigation, better technology of land use, and rationalisation of natural resource use. If pessimistic scenarios of the development of climate change in the region [64] become reality, the threat for the social and economic sector would potentially significantly increase, which should be dealt with by the private particular state and public administration.

Despite a significant general trend of the SPEI time series confirmed by the MK test, the CRD test was carried out in order to gain detailed information on trend behaviour (Figure 5). Figure 5(a) confirmed a general trend of the SPEI toward drier conditions. Although this CRD plot (Figure 5(b)) signalised fluctuation of the trend in the late 1980s and early 1990s, we argue that this could indicate regional alternation of weather circulation patterns, what was already confirmed in $[30,33,65,66]$. In addition, Faško et al. [65], Niedźwiedź [66], and Pekarova et al. [67] imply that these atmospheric circulation patterns are cyclic, with an approximately 30-year period.

Despite this, we argue that these cyclic changes will be marginal in comparison to the general drought trend because of rising temperatures (as shown in Figure 4) in the past as well as the temperature trend extrapolated in the future [29].

\subsection{Trend Analyses of SPEI by Individual Months in the} Period 1966-2013 and Agricultural Impacts. Trend analysis of SPEI values by individual months in the period 1966-2013 was performed with the aim to examine their positive (humid trend), negative, or unchanged tendencies in relation to the frequencies of drought occurrence. The results showed that, during the analysed period, the first three months of the year showed an increasing trend toward a more humid climate; although this trend was not significant in January and February, it was significant only at the $\alpha=0.25$ significance level in March. A significant difference and trend were observed in April, when we confirmed a significant increase $(\alpha=0.05)$ of the number of dry periods, i.e., arid trend. In May, we found a nonsignificant trend indicating the improved climate balance in relation to drought. All summer months (June, July, and August) showed arid trends with statistical significance between $\alpha=0.25$ and $\alpha=0.1$. In September and October, we did not record any changes in the occurrence frequency of dry or humid episodes. In November, we found decreasing (arid), statistically little significant trend $(\alpha=0.25)$. The end of the year corresponded with the projected climate change scenarios for the region in winter months [64], i.e., humid trend, but was statistically insignificant (Table 1).

The trends of the months in the period between April and August corresponded with the results of Lapin et al. [64], who analyzed the development of air moisture deficit or the increase of evapotranspiration in the region. The significant arid trend in April was the main warning signal indicating the adverse projection of the risk of drought in spring months under both optimistic and pessimistic climate scenarios in the future. Occurrences of the arid trend in April, or in spring months, were in accordance with the published results $[28,30,68]$. Since April is one of the most important months from the agricultural viewpoint $[7,27]$ and because of spring sowing and restoration of crops after winter, we consider this information very important.

The evaluation of the drought impact on agricultural production in the region expressed by the correlation between August values of the 6-month SPEI and hectare yields of oilseed rape showed a relatively tight relationship of these characteristics (Figure 2). This indicates that the climate balance in March to August, i.e., the balance of the growing season, has the greatest effect on the estimation of drought impacts. This was confirmed by Potopová et al. [7, 27] and Hlavinka et al. [8]. On the basis of the presented findings, we created a time series of August for the 6-month SPEI (Figure 6).

The analysis revealed the drop in the yield of oilseed rape or agricultural production due to drought episodes in 1967, 1968, 1983, 1991, 1992, 1998, 2000, 2003, 2007, and 2012. Smaller reductions occurred also in other periods, but listed are only those years, when the value of the index reached or exceeded -1 . However, the MK test has not confirmed a trend at $\alpha=0.05$.

The comparison of the results with the data obtained from the agricultural enterprise in the Neverice village confirmed the hypothesis and the selected methodology. Hornáček [69] presents the impacts of drought on the agricultural enterprise from 2000 to 2012. In 2000 (the index was -1.34) and 2003 (the index was -1.86), the effects of drought required establishment of a temporary water reservoir, construction of a water-feeding machine for livestock, and additional feeding of animals due to the lack of natural grazing. These measures affected the operation economy of the farm company. The drought in 2012 resulted in small growth of agricultural crops, which led to low yields.

It is also interesting to compare 6-month SPEI values with the published impacts of drought on the trees in Arborétum Mlyňany. The severe drought in 1983 (SPEI -1.27 ) caused the reduction of tree species resilience against diseases and pests (their increment and seed fertility were reduced) and the overall weakening of physiological activity of tree species (mainly aged trees, more sensitive evergreen trees, etc.), which created favorable disposition for secondary biotic pests (root rot, wood-destroying fungi, secondary insect pests, etc.) [70]. Benčať et al. [71] also stated that particularly unfavourable situation in the growing season of 1983 required a considerable financial investment to perform rescue works in the arboretum.

Our results revealed the suitability of the selected methodological approach for examining drought impacts not only on agriculture but also on forestry or regional ecological relationships. Based on this, we can state that, in 1966-2013, we observed a decreasing trend of the 6-month 


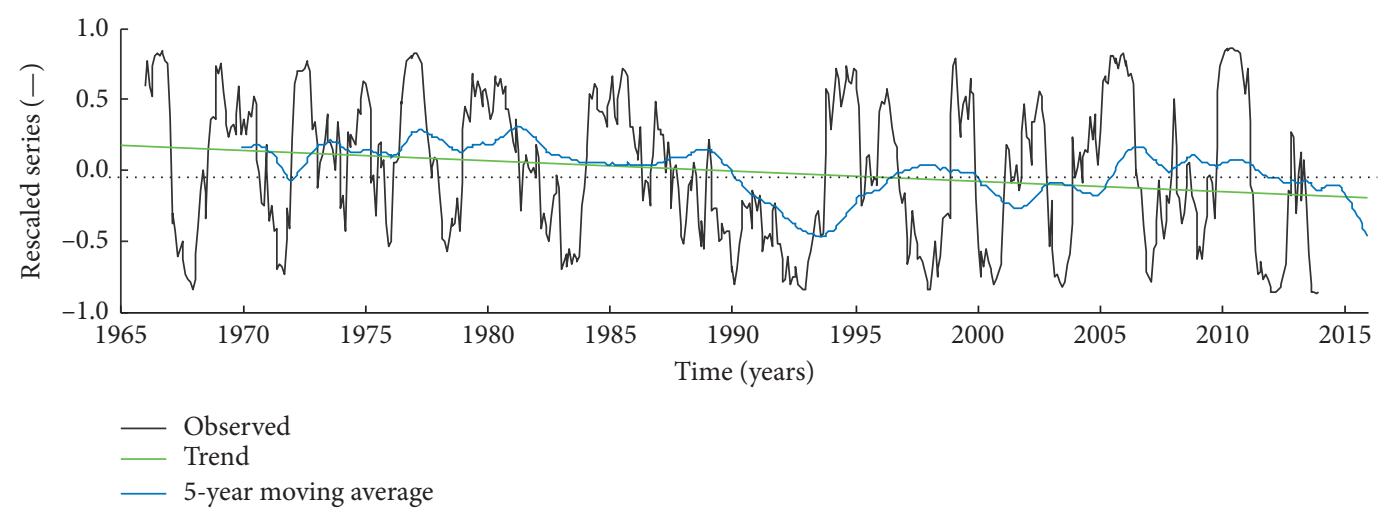

(a)



- Observed

(b)

FIGURE 5: CRD trend analysis of the 12-month SPEI at the station in Arborétum Mlyňany in 1966-2013. (a) Rescaled and aggregated time series. (b) Cumulative sums of the indices (CRD plots).

TABle 1: Trends of aridity/humidity for individual months in 1966-2013.

\begin{tabular}{lccccccccccccc}
\hline Month & Jan & Feb & Mar & Apr & May & June & July & Aug & Sep & Oct & Nov & Dec \\
\hline Trend indicator & - & - & $\boldsymbol{-}$ & $\boldsymbol{\nabla}$ & $\mathbf{-}$ & $\boldsymbol{\nabla}$ & $\boldsymbol{\nabla}$ & $\boldsymbol{\nabla}$ & $\mathbf{-}$ & $\mathbf{-}$ & $\boldsymbol{\nabla}$ & - \\
Significance level & Not sig. & Not sig. & $\alpha=0.25$ & $\alpha=0.05$ & Not sig. & $\alpha=0.1$ & $\alpha=0.25$ & $\alpha=0.1$ & Not sig. & Not sig. & $\alpha=0.25$ & Not sig. \\
\hline
\end{tabular}

$\mathbf{\Delta}$ : humid trend; $\mathbf{\nabla}$ : arid trend; $\mathbf{-}$ : no trend.

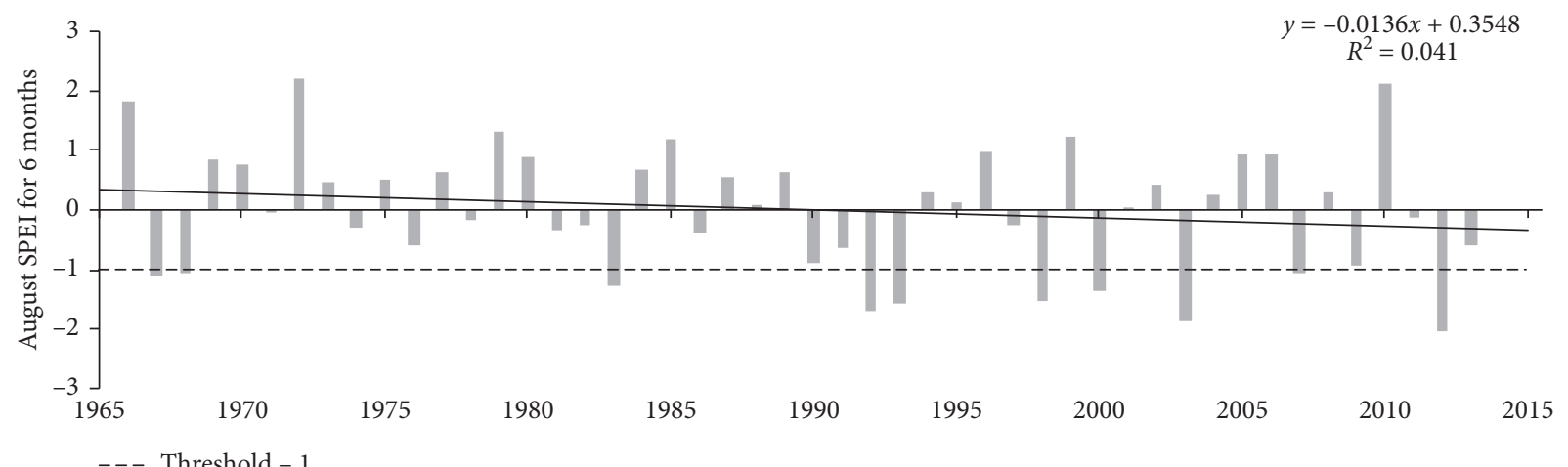

Figure 6: Values of the 6-month SPEI for August with a linear trend of the time series and an indication of the value of the index -1 (reaching/crossing this value indicates severe drought).

SPEI for August toward more arid climate. In connection with the expected development [29, 62], it may lead to a significant increase in the risk of drought for agriculture, forestry, landscape management, and nature conservation in the region. However, the MK test has not confirmed this negative trend at $\alpha=0.05$. 


\section{Conclusions}

The trend analyses showed that drought occurs in the region regularly (recurrent climate feature), while the trend analysis indicated the trend toward more arid climatic conditions. However, CRD trend analyses showed that the subtrend changed direction toward less drier conditions in the late 1980 s and early 1990s. This can indicate the changing weather circulation pattern in the region. Based on results, we argue that this change has only marginal influence on general drought trend (trend toward aridity).

The analysis of the SPEI trend in individual months showed a correspondence of our results with the published works from the area of the regional models of climate change. Analyses also showed more humid conditions in winter and drier conditions in spring and summer. As the drought trend of April should be considered the most important conclusion of the drought trend in individual months, April is one of the most important (if not the most important) months from the agricultural viewpoint (sowing, crop restoration after winter, etc.). The April SPEI trend showed a very negative trend (toward dry conditions), which can have consecutive impacts on agriculture and socioeconomic structure of the region.

The SPEI was used as an indicator of drought impacts on agriculture. Our results showed that the most significant period of year in relation to drought impacts on agriculture is March to August. Because of this, we applied the 6-month SPEI for August in trend analyses in order to gain the trend of drought influence on agriculture within the period 1966-2013.

Trend analyses showed a tendency toward drier conditions within the selected period, but the MK test has not confirmed this tendency at $\alpha=0.05$. Therefore, we argue that significant indication of worsening agricultural conditions due to drought (6-month aridity trend of the SPEI for August) cannot be convincingly confirmed by our results.

However, the analysis proved that drought occurrence has severe impacts on the agrarian sector within the region.

\section{Data Availability}

The meteorological data used to support the findings of this study were supplied by Slovak Hydrometeorological Institute under license and so cannot be made freely available. Requests for access to these data should be made to Slovak Hydrometeorological Institute, Jeséniova 17, 83315 Bratislava (e-mail: obchod@shmu.sk).

\section{Disclosure}

This manuscript is an extended version of reference [63].

\section{Conflicts of Interest}

The authors declare that there are no conflicts of interest regarding the publication of this paper.

\section{Acknowledgments}

The authors thank Prof. Jaroslav Škvarenina (Faculty of Forestry, Technical University in Zvolen) for his support throughout experienced analyses published in the cited reference [63]. This paper was supported by VEGA research projects funded by the Science Grant Agency of the Ministry of Education, Science, Research and Sport of the Slovak Republic (nos. 1/0370/18 and 1/0367/16) and projects funded by the Slovak Research and Development Agency (APVV-150425, APVV-15-0497, APVV-16-0325, and APVV-0480-12).

\section{References}

[1] M. Sivakumar, R. Motha, and H. Das, Natural Disasters and Extreme Events in Agriculture, vol. 376, Springer, Berlin, Germany, 2005.

[2] D. A. Wilhite and M. H. Glantz, "Understanding: the drought phenomenon: the role of definitions," Water International, vol. 10, no. 3, pp. 111-120, 1985.

[3] J. Spinoni, J. V. Vogt, G. Naumann, P. Barbosa, and A. Dosio, "Will drought events become more frequent and severe in Europe?," International Journal of Climatology, vol. 38, no. 4, pp. 1718-1736, 2018.

[4] A. K. Mishra and V. P. Singh, "A review of drought concepts," Journal of Hydrology, vol. 391, no. 1-2, pp. 202-216, 2010.

[5] J. Ruffault, T. Curt, N. K. Martin-StPaul, V. Moron, and R. M. Trigo, "Extreme wildfire events are linked to globalchange-type droughts in the northern Mediterranean," Natural Hazards and Earth System Sciences, vol. 18, no. 3, pp. 847-856, 2018.

[6] G. Forzieri, L. Feyen, R. Rojas, M. Flörke, F. Wimmer, and A. Bianchi, "Ensemble projections of future streamflow droughts in Europe," Hydrology and Earth System Sciences Discussions, vol. 10, no. 8, pp. 10719-10774, 2013.

[7] V. Potopová, P. Zahradníček, L. Türkott, P. Štěpánek, and J. Soukup, "The effects of climate change on variability of the growing seasons in the Elbe river lowland, Czech Republic," Advances in Meteorology, vol. 2015, Article ID 546920, 16 pages, 2015.

[8] P. Hlavinka, M. Trnka, D. Semerádová, M. Dubrovský, Z. Žalud, and M. Možný, "Effect of drought on yield variability of key crops in Czech Republic," Agricultural and Forest Meteorology, vol. 149, no. 3-4, pp. 431-442, 2009.

[9] D. A. Wilhite, "Understanding the phenomenon of drought," Hydro-Review, vol. 12, no. 5, pp. 136-148, 1993.

[10] E. O. Bekoe and F. Y. Logah, "The impact of droughts and climate change on electricity generation in Ghana," in $\mathrm{Me}$ teorology and Energy Security: Simulations, Projections, and Management, P. S. Samuel, Ed., pp. 163-178, Apple Academic Press, Oakville, Canada, 2016.

[11] A. F. Van Loon, T. Gleeson, J. Clark et al., "Drought in the anthropocene," Nature Geoscience, vol. 9, no. 2, pp. 89-91, 2016.

[12] Z. Liu, T. Törnros, and L. Menzel, “A probabilistic prediction network for hydrological drought identification and environmental flow assessment," Water Resources Research.vol. 52, no. 8, pp. 6243-6262, 2016.

[13] S. M. Vicente-Serrano, J. I. Lopez-Moreno, S. Beguería et al., "Evidence of increasing drought severity caused by temperature rise in southern Europe," Environmental Research Letters, vol. 9, no. 4, article 044001, 2014.

[14] K. R. Briffa, G. Van Der Schrier, and P. D. Jones, "Wet and dry summers in Europe since 1750: evidence of increasing 
drought," International Journal of Climatology, vol. 29, no. 13, pp. 1894-1905, 2009.

[15] P. Ciais, M. Reichstein, N. Viovy et al., "Europe-wide reduction in primary productivity caused by the heat and drought in 2003," Nature, vol. 437, no. 7058, pp. 529-533, 2005.

[16] Y. Bayissa, S. Maskey, T. Tadesse et al., "Comparison of the performance of six drought indices in characterizing historical drought for the Upper Blue Nile Basin, Ethiopia," Geosciences, vol. 8, no. 3, p. 81, 2018.

[17] S. Bachmair, M. Tanguy, J. Hannaford, and K. Stahl, "How well do meteorological indicators represent agricultural and forest drought across Europe?," Environmental Research Letters, vol. 13, no. 3, article 034042, 2018.

[18] E. Moreira, A. Russo, and R. Trigo, "Monthly prediction of drought classes using log-linear models under the influence of NAO for early-warning of drought and water management," Water, vol. 10, no. 1, p. 65, 2018.

[19] T. B. McKee, J. N. Doesken, and J. Kleist, "The relationship of drought frequency and duration to time scales," in Proceedings of the Eighth Conference on Applied Climatology, pp. 179-184, Anaheim, CA, USA, January 1993.

[20] S. M. Vicente-Serrano, S. Beguería, and J. I. López-Moreno, "A multiscalar drought index sensitive to global warming: the standardized precipitation evapotranspiration index," Journal of Climate, vol. 23, no. 7, pp. 1696-1718, 2010.

[21] W. C. Palmer, Meteorological Drought, U.S. Weather Bureau, Washington, DC, USA, 1st edition, 1965.

[22] S. Bachmair, C. Svensson, I. Prosdocimi, J. Hannaford, and K. Stahl, "Developing drought impact functions for drought risk management," Natural Hazards and Earth System Sciences, vol. 17, no. 11, pp. 1947-1960, 2017.

[23] T. A. Engda and T. J. Kelleners, "Soil moisture-based drought monitoring at different time scales: a case study for the U.S. great plains," JAWRA Journal of the American Water Resources Association, vol. 52, no. 1, pp. 77-88, 2016.

[24] P. Kolář, M. Trnka, R. Brázdil, and P. Hlavinka, "Influence of climatic factors on the low yields of spring barley and winter wheat in Southern Moravia (Czech Republic) during the 1961-2007 period," Theoretical and Applied Climatology, vol. 117, no. 3-4, pp. 707-721, 2014.

[25] L. Labudová, M. Labuda, and J. Takáč, "Comparison of SPI and SPEI applicability for drought impact assessment on crop production in the Danubian lowland and the East Slovakian lowland," Theoretical and Applied Climatology, vol.128, no. 1-2, pp. 491-506, 2017.

[26] V. Potopová, C. Boroneanţ, B. Boincean, and J. Soukup, "Impact of agricultural drought on main crop yields in the Republic of Moldova," International Journal of Climatology, vol. 36, no. 4, pp. 2063-2082, 2016.

[27] V. Potopová, P. Štěpánek, M. Možný, L. Türkott, and J. Soukup, "Performance of the standardised precipitation evapotranspiration index at various lags for agricultural drought risk assessment in the Czech Republic," Agricultural and Forest Meteorology, vol. 202, pp. 26-38, 2015.

[28] M. Zeleňáková, T. Sol'áková, P. Purcz, and D. Simonová, "Hydrological drought occurrence in Slovakia," in The Handbook of Environmental Chemistry, Springer, Berlin, Germany, 2018.

[29] M. Melo, M. Lapin, H. Kapolková, J. Pecho, and A. Kružicová, "Climate trends in the Slovak part of the Carpathians," in The Carpathians: Integrating Nature and Society Towards Sustainability, J. Kozak, O. Katarzyna, A. Bytnerowicz et al., Eds., pp. 131-150, Springer, Berlin, Germany, 2013.
[30] M. Zeleňáková, J. Vido, M. M. Portela et al., "Precipitation trends over Slovakia in the period 1981-2013," Water, vol. 9, no. 12, p. 922, 2017.

[31] L. Labudová, M. Turňa, and P. Nejedlík, "Drought monitoring in Slovakia," in Proceedings of the International Scientific Conference (Towards Climatic Services), B. Šiška, Ed., Nitra, Slovakia, September 2015.

[32] V. Zuzulová and B. Šiška, "Identification of drought in western Slovakia by palmer drought severity index (PDSI)," Acta Regionalia et Environmentalica, vol. 14, no. 1, pp. 7-14, 2017.

[33] J. Vido, T. Tadesse, Z. Šustek et al., "Drought occurrence in central European mountainous region (Tatra National Park, Slovakia) within the period 1961-2010," Advances in Meteorology, vol. 2015, Article ID 248728, 8 pages, 2015.

[34] J. Škvarenina, J. Tomlain, J. Hrvol', J. Škvareninová, and P. Nejedlík, "Progress in dryness and wetness parameters in altitudinal vegetation stages of West Carpathians: time-series analysis 1951-2007," Idojárás, vol. 113, no. 1-2, pp. 47-54, 2009.

[35] Z. Šustek and J. Vido, "Vegetation state and extreme drought as factors determining differentiation and succession of carabidae communities in forests damaged by a windstorm in the High Tatra Mts," Biologia, vol. 68, no. 6, pp. 1198-1210, 2013.

[36] Z. Šustek, J. Vido, J. Škvareninová, J. Škvarenina, and P. Šurda, "Drought impact on ground beetle assemblages (Coleoptera, Carabidae) in Norway spruce forests with different management after windstorm damage-a case study from Tatra Mts. (Slovakia)," Journal of Hydrology and Hydromechanics, vol. 65, no. 4, pp. 333-342, 2017.

[37] P. Nalevanková, M. Ježík, Z. Sitková, J. Vido, A. Leštianska, and K. Střelcová, "Drought and irrigation affect transpiration rate and morning tree water status of a mature European beech (Fagus sylvatica L.) forest in central Europe," Ecohydrology, vol. 11, no. 6, article e1958, 2018.

[38] J. Škvareninová, D. Babálová, J. Valach, and Z. Snopková, "Impact of temperature and wetness of summer months on autumn vegetative phenological phases of selected species in Fageto-Quercetum in the years 2011-2015," Acta Universitatis Agriculturae et Silviculturae Mendelianae Brunensis, vol. 65, no. 3, pp. 939-946, 2017.

[39] J. Vido, K. Střelcová, P. Nalevanková et al., "Identifying the relationships of climate and physiological responses of a beech forest using the standardised precipitation index: a case study for Slovakia," Journal of Hydrology and Hydromechanics, vol. 64, no. 3, pp. 246-251, 2016.

[40] J. Takáč, R. Skalský, A. Morávek, Z. Klikušovská, P. Bezák, and M. Bárdyová, "Spatial patterns of agricultural drought events in Danube lowland in the 1961-2013 period," in Proceedings of the International Scientific Conference from Towards Climatic Services Conference, pp. 15-18, Nitra, Slovakia, September 2015.

[41] J. Valach, “Zhodnotenie vplyvu klímy na fenológiu drevín v arboréte mlyňany (climate impact assessment on woody plants phenology in arboretum mlyňany SAS (Slovak Academy of Sciences)," Dissertation, Slovak University of Technology, Bratislava, Slovakia, 2017.

[42] HMU, Climatic and Phenological Conditions of Western Slovakia, Hydrometeorologický Ustav, Bratislava, Slovakia, 1968.

[43] SHMI, Slovak Republic-Report Containing Additional Information with Respect to the Implementation of the GCOS Plan, following the Established Reporting Guidelines FCCC/ 
SBSTA/2007/L.14, Ministry of the Environment of the Slovak Republic, Bratislava, Slovakia, 2008.

[44] G. Tsakiris and H. Vangelis, "Towards a drought watch system based on spatial SPI," Water Resources Management, vol. 18, no. 1, pp. 1-12, 2004.

[45] C. W. Thornthwait, "An approach toward a rational classification of climate," Geographical Review, vol. 38, no. 1, pp. 55-94, 1948.

[46] R. R. Heim, "A review of twentieth-century drought indices used in the United States," Bulletin of the American Meteorological Society, vol. 83, no. 8, pp. 1149-1166, 2002.

[47] E. Simelton, E. D. G. Fraser, M. Termansen et al., "The socioeconomics of food crop production and climate change vulnerability: a global scale quantitative analysis of how grain crops are sensitive to drought," Food Security, vol. 4, no. 2, pp. 163-179, 2012.

[48] B. Edwards, M. Gray, and B. Hunter, Social and Economic Impacts of Drought on Farm Families and Rural Communities: Submission to the Drought Policy Review Expert Social Panel, Australian Institute of Family Studies, Melbourne, Australia, 2008.

[49] D. Mydla, "Vplyv nedostatku zrážok v roku 2011 na prevádzku vodných stavieb vel'ké domaša a ružín," Vodohospodársky Spravodajca, vol. 53, no. 7-8, pp. 18-21, 2012.

[50] C. Schmitt, The Effects of the 2001-2002 Drought on Maine Drinking Water Supplies, The University of Maine, Orono, ME, USA, 2005.

[51] J. H. Stagge, L. M. Tallaksen, L. Gudmundsson, A. F. Van Loon, and K. Stahl, "Candidate distributions for climatological drought indices (SPI and SPEI)," International Journal of Climatology, vol. 35, no. 13, pp. 4027-4040, 2015.

[52] J. H. Stagge, L. M. Tallaksen, L. Gudmundsson, A. F. Van Loon, and K. Stahl, "Response to comment on candidate distributions for climatological drought indices (SPI and SPEI)," International Journal of Climatology, vol. 36, no. 4, pp. 2132-2138, 2016.

[53] S. M. Vicente-Serrano and S. Beguería, "Comment on "candidate distributions for climatological drought indices (SPI and SPEI)" by James H. Stagge et al.," International Journal of Climatology, vol. 36, no. 4, pp. 2120-2131, 2016.

[54] S. S. Shapiro and M. B. Wilk, "An analysis of variance test for normality (complete samples)," Biometrika, vol. 52, no. 3-4, pp. 591-611, 1965.

[55] M. G. Kendall, "A new measure of rank correlation," Biometrika, vol. 30, no. 1-2, pp. 81-93, 1938.

[56] H. B. Mann, "Nonparametric tests against trend," Econometrica, vol. 13, no. 3, pp. 245-259, 1945.

[57] S. Yue and C. Wang, "The Mann-Kendall test modified by effective sample size to detect trend in serially correlated hydrological series," Water Resources Management, vol. 18, no. 3, pp. 201-218, 2004.

[58] C. Onyutha, "Influence of hydrological model selection on simulation of moderate and extreme flow events: a case study of the blue Nile basin," Advances in Meteorology, vol. 2016, Article ID 7148326, 28 pages, 2016.

[59] E. N. Tehrani, H. Sahour, and M. J. Booij, "Trend analysis of hydro-climatic variables in the north of Iran," Theoretical and Applied Climatology, vol. 136, no. 1-2, pp. 85-97, 2019.

[60] C. Onyutha, "Statistical analyses of potential evapotranspiration changes over the period 1930-2012 in the Nile river riparian countries," Agricultural and Forest Meteorology, vol. 226-227, pp. 80-95, 2016.

[61] C. Onyutha, "Identification of sub-trends from hydro-meteorological series," Stochastic Environmental Research and Risk Assessment, vol. 30, no. 1, pp. 189-205, 2016.
[62] S. Bell and M. Moller, "The green drought," Australian Health Review, vol. 28, 2006.

[63] J. Vido, J. Valach, and J. Škvarenina, "Zhodnotenie výskytu sucha použitím indexu SPI v regióne horného požitavia," in Extrémy Oběhu Vody V Krajinè, Czech Bioclimatological Society, Mikulov, Czech Republic, 2014.

[64] M. Lapin, M. Gera, and M. Kremler, "Scenáre zmeny teploty a vlhkosti vzduchu na slovensku a možné dôsledky v mestách," Životné Prostredie, vol. 44, no. 5, pp. 227-231, 2010.

[65] P. Faško, M. Lapin, and J. Pecho, "20-year extraordinary climatic period in Slovakia," Meteorologický Časopis, vol. 11, pp. 99-105, 2008.

[66] T. Niedźwiedź, R. Twardosz, and A. Walanus, "Long-term variability of precipitation series in east central Europe in relation to circulation patterns," Theoretical and Applied Climatology, vol. 98, no. 3-4, pp. 337-350, 2009.

[67] P. Pekarova, P. Miklanek, and J. Pekar, "Long-ermtrends and runoff fluctuations of European rivers," in Proceedings of the Fifth FRIEND World Conference. Climate Variability and Change-Hydrological Impacts, S. Demuth, A. Gustard, E. Planos et al., Eds., vol. 308, pp. 520-525, IAHS Publication, Havana, Cuba, November 2006.

[68] V. Novák and I. Žaludná, “Očakávané zmeny evapotranspirácie a produkcia biomasy nížinných oblastí slovenska v podmienkach globálnych zmien klímy," in XII. ČeskoSlovenská Bioklimatologická Konference, Czech Bioclimatological Society, Velké Bílovice, Czech Republic, 1996.

[69] P. Horňáček, Personal Communication, Pol'nohospodárske Družstvo Neverice, Zlaté Moravce, Slovakia, 2014.

[70] P. Hrubík, "Charakteristika klimatických podmienok Arboréta Mlyňany SAV a ich vplyv na cudzokrajné dreviny v posledných rokoch (1971-1986)," Rosalia, vol. 4, pp. 81-112, 1987.

[71] F. Benčat', P. Hrubík, and I. Tábor, "Auswertung der extremen klimabedingungen im jahr 1983 und ihr einfluss auf die gehölze in dem arboretum mlynany," Folia Dendrologica, vol. 13, pp. 331-356, 1986. 

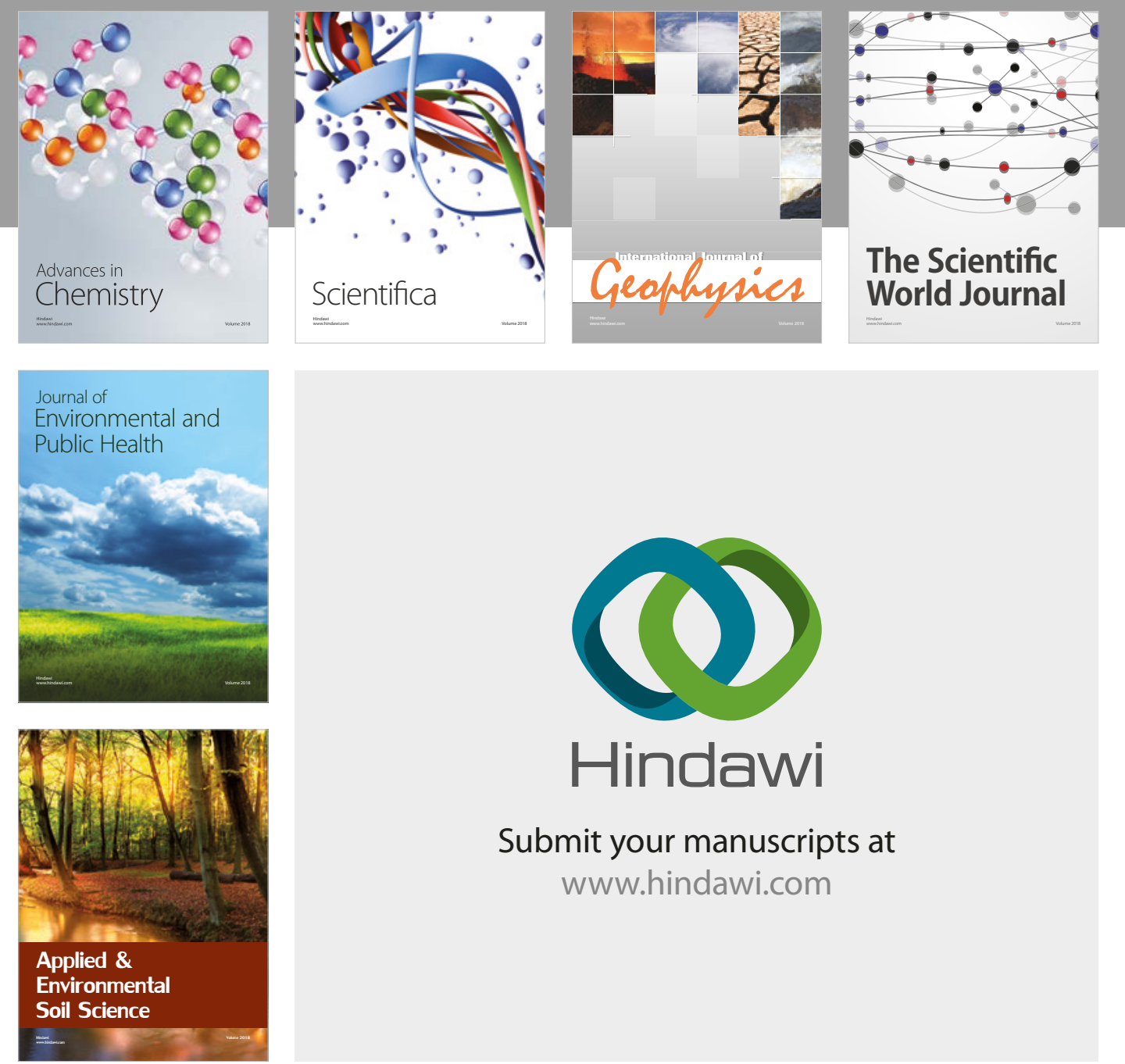

The Scientific

\section{World Journal}
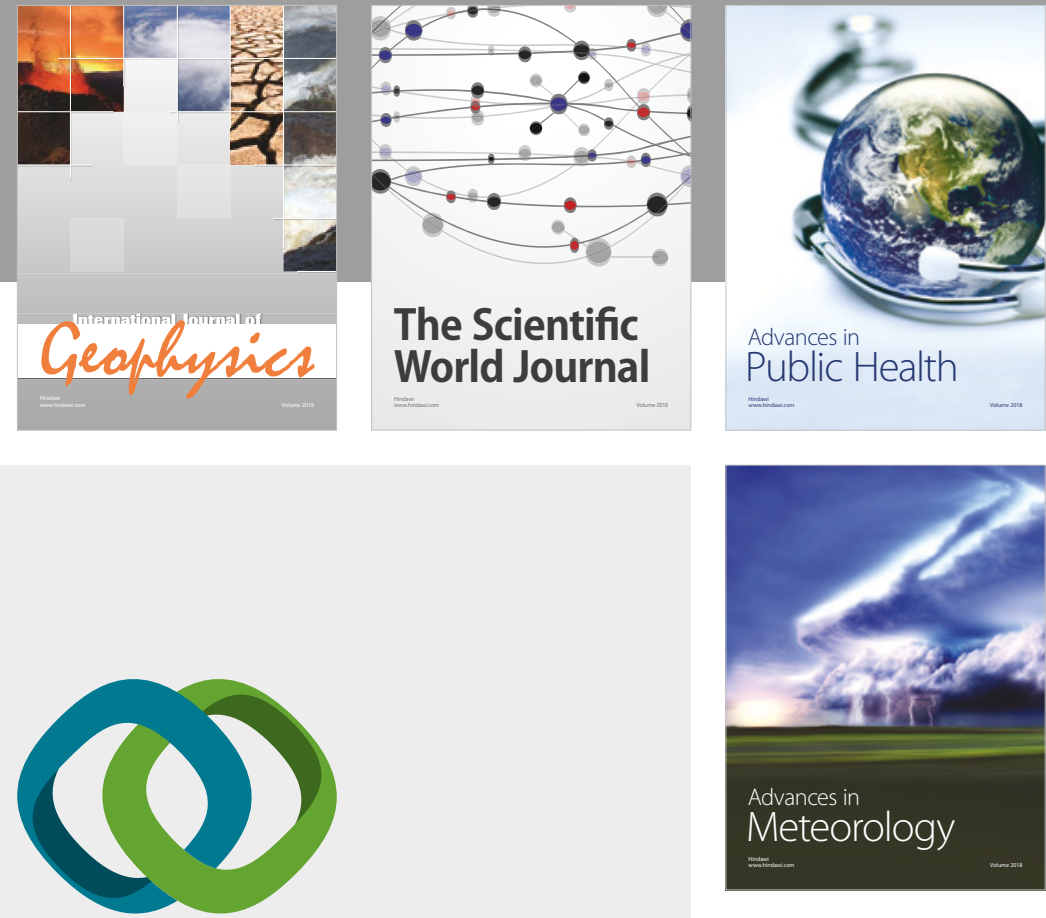

Advan

Public Health

\section{Hindawi}

Submit your manuscripts at

www.hindawi.com
